Electronic scientific and practical journal

\title{
INTELLECTUALIZATION OF LOGISTICS AND SUPPLY CHAIN MANAGEMENT
}

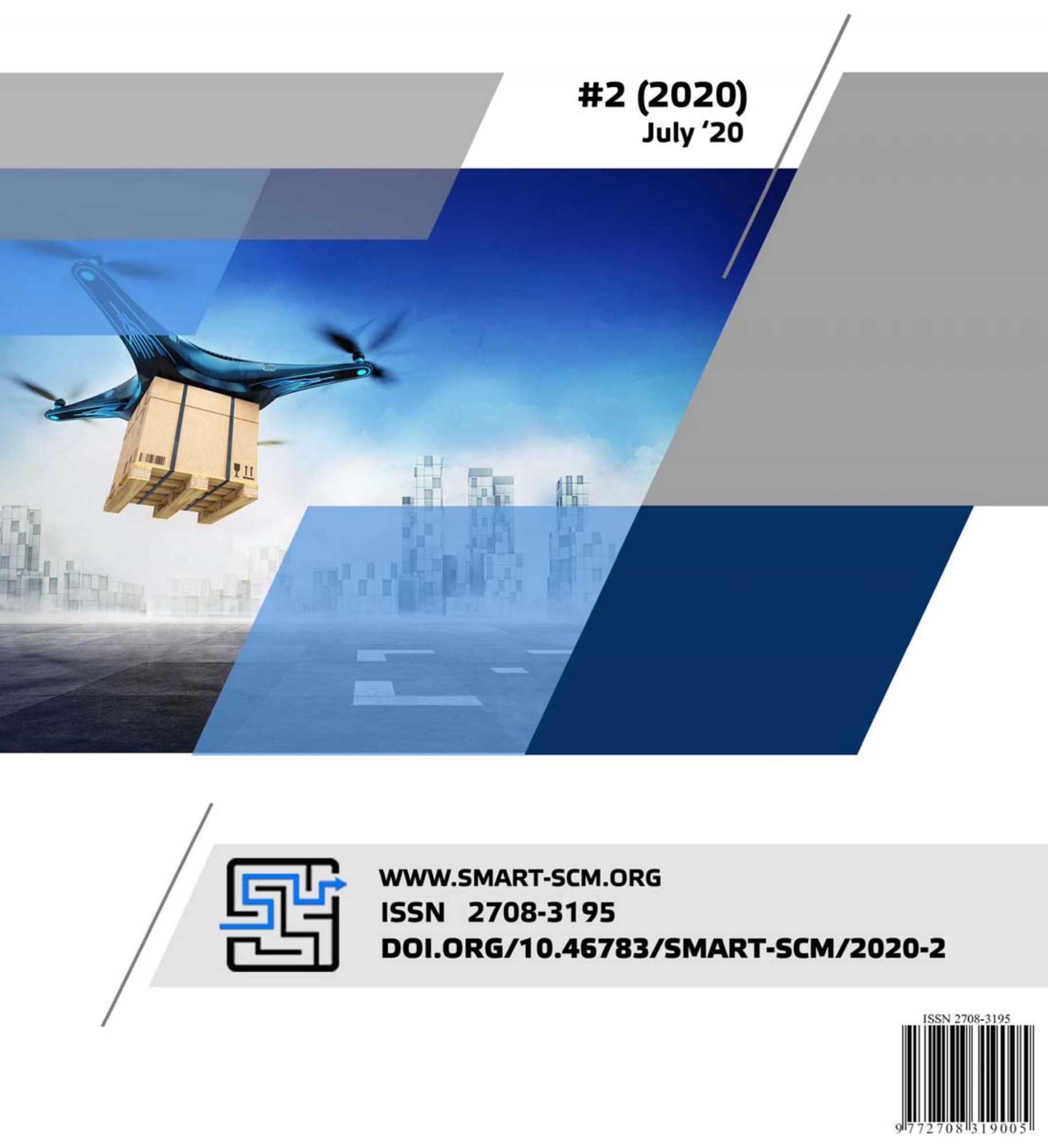




\section{Electronic scientific and practical collection
INTELLECTUALIZATION OF LOGISTICS
AND SUPPLY CHAIN MANAGEMENT}

Electronic scientific and practical publication in economic sciences

ISSN 2708-3195

DOl: https://doi.org/10.46783/smart-scm/2020-2

Released 6 times a year

№ 2 (2020)

July 2020

Kyiv - 2020 
Founder: Viold Limited Liability Company

Editor in Chief:

Deputy editors-in-chief:

Technical editor:

Executive Secretary:
Hryhorak M. Yu. - Doctor of Economics, Ass. Professor.

Koulyk V. A. - PhD (Economics), Professor.

Marchuk V. Ye. - Doctor of Tech. Sci., Ass. Professor.

Harmash O. M. - PhD (Economics), Ass. Professor.

Davidenko V. V. - PhD (Economics), Ass. Professor.

\section{Members of the Editorial Board:}

SWIEKATOWSKI Ryszard - Doctor of Economics, Professor (Poland);

POSTAN M. Ya. - Doctor of Economics, Professor;

TRUSHKINA N. V. - PhD (Economics), Corresponding Member of the Academy;

KOLOSOK V. M. - Doctor of Economics, Professor;

ILCHENKO N. B. - Doctor of Economics, Ass. Professor;

SOLOMON D. I. - Doctor of Economics, Professor (Moldova);

ALKEMA V. H. - Doctor of Economics, Professor;

Henryk DŹWIGOŁ - PhD (Economics), Professor (Poland);

SUMETS O. M. - Doctor of Economics, Ass. Professor;

STRELCOVÁ Stanislava - PhD (Economics), Ass. Professor, (Slovakia);

RISTVEJ Jozef (Mr.) PhD (Economics), Professor, (Slovakia);

ZAMIAR Zenon - Doctor of Economics, Professor, (Poland);

SMERICHEVSKA S. V. - Doctor of Economics, Professor;

GRITSENKO S. I. - Doctor of Economics, Professor;

KARPENKO O. O. - Doctor of Economics, Professor;

PATKOVSKYI S. A. - Business practitioner.

The electronic scientific and practical journal is registered in international scientometric data bases, repositories and search engines. The main characteristic of the edition is the index of scientometric data bases, which reflects the importance and effectiveness of scientific publications using indicators such as quotation index, h-index and factor impact (the number of quotations within two years after publishing).

In 2020, the International Center for Periodicals (ISSN International Center, Paris) included the Electronic Scientific and Practical Edition "Intellectualization of Supply Chain Management" in the international register of periodicals and provided it with a numerical code of international identification: ISSN 2708-3195 (Online).

Recommended for dissemination on the Internet by the Academic Council of the Department of Logistics NAU (No. 7 of February 26, 2020). Released 6 times a year. Editions references are required. The view of the editorial board does not always coincide with that of the authors.

t.me/smart_scm facebook.com/Smart.SCM.org twitter.com/ScmSmart

DOI: https://doi.org/10.46783/smart-scm/2020-2 e-mail: support@smart-scm.org тел.: (063) 593-30-41

https://smart-scm.org 


\section{Contents}

INTRODUCTION

GRITSENKO S.I. Doctor of Economics, Professor, Professor of Logistics Department National Aviation University (Ukraine), KARPUN O.V. PhD of Economics, Associate Professor, Associate Professor of Logistics Department National Aviation University (Ukraine)

CREATION OF AVIATION TRANSPORT AND LOGISTIC CLUSTERS NETWORK

$7-15$

KOSTYUCHENKO L.V.PhD (Economics), Associate Professor, Associate Professor of Logistics Department National Aviation University (Ukraine), KOSTIUCHENKO A.V. lieutenant-colonel Armed Forces of Ukraine, Kyiv, (Ukraine)

THE LOGISTICAL SUPPORT SYSTEM ELEMENTS FOR THE PREPAREDNESS FOR MILITARY OPERATIONS

MARCHUK V.Ye. Doctor of Engineering, Associate Professor, Professor of Logistics Department National Aviation University (Ukraine), HARMASH O.M. PhD (Economics), Associate Professor, Associate Professor of Logistics Department National Aviation University (Ukraine), OVDIIENKO O.V. PhD student, Assistant at Logistic Department at National Aviation University (Ukraine)

WORLD TRENDS IN WAREHOUSING LOGISTICS

PATKOVSKYI Sergii Business practitioner; Business development manager, emerging markets Kuehne + Nagel Inc., Chicago, IL (USA), LYTVYNENKO S.L. PhD (Economics), Associate Professor, Associate Professor of International Economics Department National Aviation University (Ukraine) THE WAYS OF SUPPLY CHAIN RESPONSIVENESS INCREASE AT TIME OF PORT INFRASTRUCTURE AND TRANSPORTATION ASSETS PRODUCTIVITY DISRUPTION

POPOVYCHENKO I.V. Doctor of Economic, Professor, Head of Economics and Entrepreneurship Department State Higher Educational Establishment "Prydniprovs'ka State Academy of Civil Engineering and Architecture", Dnipro, (Ukraine), SPIRIDONOVA K.O. PhD (Economics), Associate Professor, Associate Professor of Economics and Entrepreneurship Department State Higher Educational Establishment "Prydniprovs'ka State Academy of Civil Engineering and Architecture", Dnipro, (Ukraine) APPLICATION OF FUNCTION COST ANALYSIS AND NETWORK SCHEDULING IN LOGISTICS COSTMANAGEMENT 
KOLOSOK V.M. Doctor of Economic, Professor, Head of the Department of Transport Management and Logistics Department Priazovsky State Technical University (Ukraine), LAZAREVSKA Yulianna. PhD student Donetsk National Technical University (Ukraine) EFFICIENCY OF DIGITAL COMMUNICATIONS IN THE LOGISTICS BUSINESS: EVALUATION INDICATORS

CHORNOPYSKA N.M. PhD (Economics), Associate Professor, Associate Professor at department marketing and logistics at Lviv Polytechnic National University (Ukraine), BOLIBRUKH L.I. Student at department marketing and logistics at Lviv Polytechnic National University (Ukraine)

THE INFLUENCE OF THE COVID-19 CRISIS ON THE FORMATION OF LOGISTICS QUALITY

KOPISHYNSKA K. O. PhD (Economics), Senior Lecturer of Department of Management, National Technical University of Ukrainen "Igor Sikorsky Kyiv Polytechnic Institute" (Ukraine) CURRENT STATE AND PROSPECTS OF DIGITAL TRANSFORMATION OF THE TRANSPORT AND LOGISTICS SECTOR OF UKRAINE

HRYHORAK M. Yu. ., Doctor of Science in Economics, Associate Professor, Head of Logistics Department of National Aviation University (Ukraine), KARPENKO 0.0., Doctor of Science in Economics, Professor, Professor by Water Transport Management and Economics Department, State University of Infrastructure and Technologies (Ukraine), SEMERIAHINA M. M., Senior Lecturer of Logistics Department of National Aviation University (Ukraine)

FORMATION OF THE MULTIMODAL TRANSPORT ECOSYSTEM IN UKRAINE

The History of Science.

MIROTIN Leonid Borysovych-the Doctor of Technical Sciences, Professor 
UDC 656.062:658.7:658:81

DOI: https://doi.org/10.46783/smart-scm/2020-2-2

JEL Classification: F 42, F 53, H56, P41, P47.

Received: 24 July 2020

Kostiuchenko L.V. PhD of Economics, Associate Professor, Associate Professor of Logistics Department National Aviation University (Ukraine)

ORCID - 0000-0002-7635-5153

Researcher ID - S-7795-2018

Scopus author id:

Kostiuchenko A.V. lieutenant-colonel Armed Forces of Ukraine, Kyiv, Ukraine (Ukraine)

ORCID - 0000-0002-5585-3831

Researcher ID -

Scopus author id:

\section{THE LOGISTICAL SUPPORT SYSTEM ELEMENTS FOR THE PREPAREDNESS FOR MILITARY OPERATIONS}

Lesia Kostiuchenko, Andrii Kostiuchenko. "The logistical support system elements for the preparedness for military operations». The modern views of the essence and content of logistics support for the preparedness for military operations for military logisticians and academic experts differ in some way. The main differences in the views of the authors are based on defining the boundaries of the logistics system. In particular, military traditions significantly narrow the field of logistics management of the processes of providing structural units under certain conditions. At the same time, approaches to the organization of logistical support of rear structures and units that perform military operations are different algorithms. On the contrary, according to the academic vision, the logistics of military units is only part of the macro-logistics system. That is why the purpose of this study is to search a science-based system of supporting of all participants in the logistics chain for the preparedness for military operations.

The implementation project of key elements of the logistical support system of readiness of the armed forces units for military operations is offered. The implementation of these proposals is expected to achieve a synergistic effect, namely: a powerful reduction in time, which is very critical in terms of active military operations; achieving high quality of logistic support operations; reducing the prime cost of operations, especially one-time or functionally unacceptable for military units; quick reaction to change of conditions, etc. Such results can accelerate the practical implementation of NATO standards in the armed forces.

Keywords: logistics support, logistics system, support of military units, outsourcing of logistics operations, resource potential of military logistics.

Леся Костюченко, Андрій Костюченко. «Елементи системи логістичного забезпечення готовності до військових операчій». Сучасне бачення військових логістів та академічних експертів змісту логістичного забезпечення готовності до військових дій грунтуються на визначенні меж логістичної системи. Зокрема, військові традичії значно звужують сферу управління логістикою прочесів забезпечення структурних підрозділів за певних умов. У той же час, підходи до 
організації матеріально-технічного забезпечення тилових структур і підрозділів, які виконують військові дії є різними алгоритмами. Навпаки, відповідно до академічного бачення, логістичне забезпечення військових підрозділів є лише частиною макрологістичної системи. Саме тому метою чього дослідження $\epsilon$ пошук науково обгрунтованої системи підтримки всіх учасників логістичного ланцюга щодо готовності до військових операцій.

Запропоновано проект впровадження ключових елементів системи логістичного забезпечення готовності підрозділів збройних сил до військових операчій. Результатом реалізачії наведених пропозичій очікується досягнення синергічного ефекту, а саме: потужне скорочення витрат часу, що єдуже критичним за умов ведення активних військових операчій; досягнення високої якості операчій логістичного забезпечення; зниження собівартості операчій, особливо разових або функціонально-неприйнятних для військових підрозділів; швидка реакція на зміни умов тощо. Такі результати можуть прискорити практичну реалізачію стандартів НАТО узбройних силах.

Ключові слова: логістичне забезпечення, логістична система, забезпечення військових підрозділів, аутсорсинг операцій логістичного забезпечення, ресурсний потенціал військової логістики.

Леся Костюченко, Андрей Костюченко. «Элементы системы логистического обеспечения готовности к военным операциям». Видение военных логистов и академических экспертов на сущность логистического обеспечения готовности к военным операциям основываются на определении границ логистической системы. В частности, военные традиции существенно сужают сферу управления прочессами обеспечения структурных подразделений в конкретных условиях. При этом подходы к организации материально-технического обеспечения тыловых структур и подразделений, выполняющих военные операчии, являются разными алгоритмами. И, наоборот, в соответствии с академическим видением, логистическое обеспечение военных подразделений является лишь частью макрологистической системы. Поэтому, челью данного исследования является поиск научно-обоснованной системы поддержки всех участников логистической чепочки касательно их готовности к военным операциям.

Предложен проект внедрения ключевых элементов системы логистического обеспечения готовности подразделений вооруженных сил к военным операциям. Результатом реализачии приведенных предложений ожидается достижение синергетического эффекта, в частности: мощное сокращение затрат времени, что является критичным в условиях ведения активных операчий, достижение высокого качества операчий логистического обеспечения; сокращение себестоимости операций, особенно разовых или функционально-неприемлемых для военных подразделений; быстрая реакция на изменения и пр.

Ключові слова: логистическое обеспечение, логистическая система, обеспечение военных подразделений, ресурсный потенциал военной логистики.

Introduction. Modern military-political Ukrainian realities require the formation of a single effective logistic support system of military units. The main strategic goals of our country must correlate with NATO logistics standards and instructions. So it's very important to search a science-based system of supporting of all participants in the logistics chain for the preparedness for military operations.

Analysis of recent researches and publications. Modern scientific publications contain a large amount of material devoted to the logistic support of different activities. The article [4] explained the content of the term "logistics of the defense sector". This topic has also gained popularity in the military sphere. In particular, in June 2020 took place Scientific and practical webinar on the topic "Improving the logistics of the Armed Forces of Ukraine based on the experience of the joint forces operation" in the National University of Defense of Ukraine named after I. Chernyakhovsky. Most of the reports were based on the principles of the NATO logistics experience.

There is interpretation of the terms "logistic support", "material and technical 
support", "logistics management bodies", "forces and means of logistics" in the Resolution of the Cabinet of Ministers [10].

So, logistic support is a complex of "measures from: logistic support planning; identification of armaments needs, special and vehicles, combat (military and special) equipment, material and technical means and services; design, development (modernization and modification) of armaments, military and special equipment and logistical means, their purchase, supply, storage, repair, maintenance, operation control; sale, write-off and utilization of surplus weapons, military and special equipment and material and technical means; planning and implementation of military transportation by all modes of transport; purchase of works and services of bath and laundry, trade and household services; catering; quartering of troops (forces, bodies); procurement or construction, maintenance, operation of military infrastructure" [10].

The material and technical means include: "missiles, ammunition, military equipment, fuel, special liquids, food, belongings, medical and other property, in addition to real estate, which are necessary to ensure the components of the defense forces in the performance of their defense tasks, protection of its sovereignty, territorial integrity and inviolability" [10].

Logistics support bodies are "military management bodies (management bodies) of the Armed Forces, other military formations, of the law enforcement and intelligence agencies, the State Special Communications, the State Emergency Service, which are authorized by law to provide tasks for logistic support". [10]

The forces and means of logistic support are: "arsenals, bases, support centers, warehouses, automobile and repair and restoration military units (subdivisions) of the Armed Forces, other components of the defense forces, which are designed to maintain stockpiles of weapons, military and special equipment, material and technical means, their transportation, maintenance and repair"[10].

In particular in the NATO Logistics Handbook (1997) we read "the definition of logistics by NATO covers a wide range of responsibilities that fall into different areas of the NATO organization" [8]. NATO logistics is largely identified with the concept of logistic supporting. So NATO Logistics Handbook offers the two aspects of logistics have to do with the relationship between the producer and the consumer, and two additional aspects that have to do with how logistics functions are performed [8]:

- Cooperative Logistics is the totality of bilateral and multilateral consumer and production logistics arrangements to optimize in a coordinated and rationalized way, logistics support to NATO forces. The aim of NATO Cooperative Logistics is to achieve cost savings through economy of scale and increased efficiency in peacetime, crisis and wartime logistics support. Development of NATO Cooperative Logistics arrangements is largely facilitated by the use of NATO Production and Logistics Organizations (NPLOs), particularly the NATO Maintenance and Supply Agency (NAMSA) using modern techniques in the field of materiel management and procurement.

Multinational Logistics must function as an effective force multiplier. With the risk now omni-directional, the diminishing logistic support resources, and the principle of shared logistics responsibilities, the evolution toward multinational logistics becomes of utmost importance. It is proposed that this term cover: "The different means to logistically support operations other than purely national, such as multinational integrated logistic support, role specialization support and lead nation support" [8]. There is classes by NATO of supply are established in the fiveclass system of identification as follows in the Table 1: 
Table 1.

Classes of supply by NATO standards

\begin{tabular}{|c|c|}
\hline Class & Definition \\
\hline Class I. & $\begin{array}{l}\text { Items of subsistence, e.g. food and forage, which are consumed by personnel or } \\
\text { animals at an approximately uniform rate, irrespective of local changes in combat } \\
\text { or terrain conditions. }\end{array}$ \\
\hline Class II. & $\begin{array}{l}\text { Supplies for which allowances are established by tables of organization and } \\
\text { equipment, e.g. clothing, weapons, tools, spare parts, vehicles }\end{array}$ \\
\hline Class III. & $\begin{array}{l}\text { Petroleum, oil and lubricants (POL) for all purposes, except for operating aircraft } \\
\text { or for use in weapons such as flamethrowers, e.g. gasoline, fuel oil, greases, coal } \\
\text { and coke. }\end{array}$ \\
\hline Class III a & Aviation fuel and lubricants \\
\hline Class IV. & $\begin{array}{l}\text { Supplies for which initial issue allowances are not prescribed by approved issue } \\
\text { tables. Normally includes fortification and construction materials, as well as } \\
\text { additional quantities of items identical to those authorized for initial issue (Class } \\
\text { II) such as additional vehicles. }\end{array}$ \\
\hline Class V. & Ammunition, explosives and chemical agents of all types \\
\hline
\end{tabular}

Thus, according to NATO logistics as logistics supporting is in fact material and technical supporting for the defense sector. The same interpretation and content of logistics is followed by Ukrainian military logisticians.

The basic principles on which the logistical support of the defense forces is based during their preparation and application are [10]:

- centralization of management to achieve effective implementation of tasks to meet the common needs of the components of the defense forces with the involvement of all available forces and means of logistical support of the defense forces components, taking into account their capabilities, as well as the efficient use of available resources;

- priority and sufficiency of logistical support for continuous and full satisfaction of the needs of the defense forces components in armaments, military and special equipment, material and technical means, as well as directing the main efforts of logistic support by the priority tasks performed by the defense forces during their preparation and the application;

- joint implementation of tasks to meet the needs of the defense forces by the joint efforts of central executive bodies, other state bodies, forces and means of which are involved in the defense forces, the Armed Forces, other defense forces, taking into account their capabilities;

- interaction and coordination of actions between of the defense forces components and central (local) executive bodies, local governments, other state bodies, enterprises of the defense industry, other enterprises, institutions and organizations, regardless of ownership, on the provision of weapons, military and special equipment, material and technical means and services during the training of defense forces and during their application;

- functional compatibility of organizational structures of management bodies of logistical support of defense forces components and the forces and means subordinated to them;

- cooperation of the constituent forces of the defense with the bodies of foreign states, international organizations and the armed forces of other states in matters of providing the constituent forces of the defense with material means and services during their preparation and application in accordance with the powers defined by law.

The speakers of Scientific and practical webinar [11] somewhat clarified the above principles of logistical support of the rear and troops in operations. Emphasis was placed on 
the efficiency of the use of the received military property / services and infrastructure facilities, the flexibility of processes and the stability of logistical support as well as of the possibility of integrating the logistics system of the Armed Forces of Ukraine or its individual elements during joint operations with the armed forces of NATO member states. The last thesis brings logistical support to the macro level.

Military logisticians define the ultimate goal of logistics as the acquisition by the Armed Forces of Ukraine of such qualities that will ensure the ability in peacetime to ensure the combat and mobilization readiness of forces in their new form. And in wartime, the ultimate goal of logistics is to increase their combat capabilities at all levels of armed struggle: strategic, operational, and tactical. So the essence of improving the provision by military property to forces services of in peacetime with the introduction of logistics in the Armed Forces of Ukraine is the need of [11]:

- reviewing the functions of the elements of the military property supply system and the system as a whole;

- identifying the priority, sufficiency and redundancy or duplication of supplies;

- transition to new organizational and staffing structures, to build a vertical of their management, a system of staffing and training of services included in the logistics system;

- development of modern approaches to the accumulation, structure and use of military stockpiles, organization of military transportation and evacuation, technical equipment (military units and subdivisions, institutions and medical establishments);

- improvement of economic activity, quality of planning, efficiency of infrastructure operation;

- optimization of costs for the purchase and provision of services, etc.

In the context of European integration and new tasks of the Armed Forces of Ukraine related to Ukraine's participation in environmental protection, anti-terrorist operation, peacekeeping activities under the auspices of NATO and the UN, webinar participants [11] stressed the need to reform troops (forces), types of logistics, technical and medical support in accordance with NATO standards.

In this context, the organization of logistics management is to create an appropriate management system, maintaining any level of its readiness, building and ensuring the smooth carrying operations (combat operations). In addition, they formulated the main transformation directions of the existing system of military property and services of the Ukrainian Armed Forces, such as: complete change of all rules and procedures of procurement, introduction of electronic procurement and electronic document flow. This, according to military logisticians, will contribute to the creation of an effective logistics system of the Ukrainian Armed Forces, capable of planning and managing the processes of logistics of troops (forces) both in peacetime and in special periods and will be compatible with the NATO system.

The generalized modern vision of the Armed Forces of Ukraine on the formation of the logistics system is published in [13]:

- "Logistics forces will continue to develop in order to maintain armaments and military equipment, material resources and provide them to troops (forces), all components of the defense forces, as well as to create an effective system of infrastructure for troops (forces), which will ensure guaranteed performance of such basic tasks: real estate management, ensuring their settlement in permanent locations and during the performance of tasks in operations, maintenance of facilities and means of infrastructure, energy and utilities.

- Determining the needs and planning of logistic support will be entrusted to the logistics units (J, G, A, N, S-4) of the General Staff of the Armed Forces of Ukraine, commands of species, certain types of troops (forces), operational (air) commands and military units. 
- The organization of logistical and infrastructure support will be entrusted to the Logistics Forces Command.

- In the medium and long term, units and subdivisions of logistical support will be consolidated into joint logistic support centers".

It's difficult to disagree with the fact that the logistics management system must have a high combat readiness, survivability, resilience and provide the possibility of both centralized and decentralized management. So, the system of troops management automation is a set of the means of automation of management united by a uniform information space which provide support of decision-making, their delivery to executors and implementation of control over their execution. Ultimately, the troops management automation system has to ensure that such operations are performed [11]:

- collection, processing, analysis and evaluation of data on the location, condition, composition and stocks of material means of troops;

- reception, processing and display of commands and signals of combat control "from top to bottom" - from the highest body of military management;

- formation and issuance of confirmations of received signals and commands, exchange of formalized and informal information;

- management of troops in different states (in the course of daily activities, during the transition from peacetime to wartime and in wartime when solving operational tasks);

- automation of planning and management processes of the regular forces and means;

- information protection and cyber security;

- integration of existing automation systems and tools.

The skills of synchronization of each combat operations function with the general picture of operation in units of armed forces train during preparation, carrying out rehearsals of logistics within the limits of one or limited number of combat tasks. Such support rehearsals allow commanders to see the big picture and make decisions in real time. Their goal is to harmonize logistics with maneuvering plans, not to respond to changes in combat. One of the webinar speakers [11] also noted that even when units adhere very closely to the concept of supply, the changes could place excessive numbers of troops and armaments in the way of movement and thus cause damage due to a lack of prior planning with support units. In practice, however, supplies often do not provide adequate combat support as a result of brigade support, an advanced support company (FSC) and a supported maneuvering battalion. In general, the support rehearsal creates future decisions and causes changes in logistics requirements and solves the question of: who, what, when, where and how.

Thus, based on the results of the support rehearsal, the units have to answer the following questions [11]: What is the current status of logistics in each echelon? What are the problems with combat power that affects units? What are the ongoing supply arrangements in the echelon supervision units? What is the priority of support? What is the priority of the service and does it support the main efforts? What is the priority of supply? What is the priority of the care operation relative to weapons, medical assets etc.? When will the units need to be replenished and what are the signs for replenishment? What is the action plan for mass losses?

Military experts are convinced that without proper logistics planning and synchronization for all teams, the battle will be lost. With which we completely agree too. Therefore, each unit has to integrate the rehearsal of the support according to its own timeline of continuous training, as well as the decision-making process and define standard operating procedures. $[9,11]$.

However, taking into account the current unstable military-political situation in 
Ukraine, it's appropriate to take into account the academic understanding and vision of the formation of a logistical support system for military operations readiness. First of all, it is worth paying attention to two key principles of logistics management - system-process and variable-situational principles, which are described in detail in [6, pp. 56-66].

In the monograph [3, pp. 185-189] a distinctive feature of the logistics economy is the focus on market segments, territories, regions and the country as a whole, not only it, but not only on enterprises, which reflects only the corporate goals of logistics services. The concept of economic space of logistics is revealed, which correlates with the concept of logistics system, the objects of which are enterprises of different branches of economy, logistics capacities, transport communications, telecommunication systems, etc., These objects interact in accordance with the spatial (territorial) structure of the economy and the spatial (territorial) organization of economic entities, united by material and accompanying flows. Thus, according to Professor Grigorak M.Yu., it's important to study first the economic relations that arise in the economic space of logistics [3. pp. 185-189], and then work on the coordination of logistics flows.

"In the theoretical and cognitive aspect of the logistics system" the Professor Alkema V.H. writes in his own monograph [2] "it's a subsystem of the economic system. Its feature at the macro level as an object of management is a set of interconnected and interacting logistics entities that develop the total resource potential, organized in the form of logistics flows by optimizing and streamlining them". [2, p. 83].

This understanding of the logistics system as an economic space suggests that logistics is an element of the entity potential, namely its resource component. According to Professor Alkema V.G., the definition of the term "potential" is more widely used in relation to a particular type of resources or their combination, and two "resource" positions are distinguished [1]:
1) potential as a set of resources without taking into account their relationships and participation in the production process is a generalized, collective characteristic of resources (quantity and quality of resources that a system has);

2) as a set of resources capable of producing a certain amount of material goods, as it characterizes the resources of production, their quantitative and qualitative parameters, which determine the maximum capacity of society to produce material goods at any given time. That is, it's a reflection of the ability to achieve high end results through the most efficient use of available resources. After all, the concept of "resource" belongs to the elements of the operational process and is, in essence, opportunities to achieve goals that are determined by potential. Professor Alkema V.G. identifies two alternative scientist's views on the concept of resource potential [1]:

First, as a set of all resources of the enterprise, providing the opportunity to obtain the maximum economic effect at a given time;

Secondly, as a system of resources, an interconnected set of material, energy, information tools, as well as the themselves workers, who use (or can use) them in the production of material goods and services.

The resource approach to the separation of logistics systems means that economic entities operate in conditions of limited resources and interact with each other in accordance with economic laws in order to [3 ]: maximize the results of their activities (with a given amount of production resources to strive for maximum output); minimize the cost of production resources under a certain volume of production; optimize results (costs and results have to be in a certain optimal combination).

The functioning of organizations participants in the economic system of the highest order can't do without interaction with other organizations, components of market infrastructure. In particular, "economic and organizational relations of 
enterprises-producers of goods and services make it possible to carry out exchange processes and bring the manufactured products to the final consumer. Therefore, ... today it is not the availability of own resources in the enterprise that comes to the fore, but the opportunity and ability to use available external resources within the framework of mutually beneficial cooperation of companies in the supply chain". [3, p. 186]. According to the author [3], the resource concept of the logistics system formation involves the spatial component of the logistics system resources and the decomposition of their elements (on types and subtypes of resources by links of the logistics system). Logistics system resources include [3]: tangible assets (fixed assets, current assets, investments) transaction costs; human resources (qualification, skills, activity / effectiveness) partnership; intangible assets (strategic assets, own technologies, reputational assets, goodwill) - achieving a synergistic effect.

The purpose and objectives of the study. The analysis of publications of the above authors shows, that the views of the essence and content of logistics support for the preparedness for military operations for military logisticians and academic experts differ in some way. The main differences in the views of the authors are based on defining the boundaries of the logistics system. In particular, military traditions significantly narrow the field of logistics management of the processes of providing structural units under certain conditions. At the same time, approaches to the organization of logistical support of rear structures and units that perform military operations are different algorithms. In contrast, the academic vision of the logistics support of military units is only part of the macro-logistics system. That is why the purpose of this study is to search a science-based system of supporting of all participants in the logistics chain for the preparedness for military operations.

Basic material and results. Given the resource concept set out in the monograph [3], we can agree with the author that in the theoretical and methodological sense the most developed concept for the formation of the national logistics system should be considered the concept of synergy and system dynamics, which are combined in an economic theory system. Depending on the features of spatio-temporal localization among economic systems, there are four basic groups [3, p. 187 ]: a) environmental type systems for which spatial and temporal boundaries are not defined (socio-economic institutions, business climate, infrastructure, Internet, etc.); b) process-type systems for which temporal but not known spatial boundaries are known (logistic processes, dissemination of innovations, knowledge transfer); c) system-type systems for which both temporal and spatial boundaries are defined (construction of logistics centers, production development of a new type of product, holding mass events); d) object type systems for which spatial but not temporal boundaries are defined (country, region, enterprise, etc.).

For example, based on the principles of NATO Logistics and the content of the resource concept, Cooperative Logistics is an environmental type system, because it's the combination of bilateral and multilateral consumer and production logistics arrangements. It should be added that such a combination makes it possible to achieve a synergistic effect. And Multinational Logistics is an object type system because it covers the different participants and means to logistically support operations. So, "clear spatial and temporal determination of subsystems makes it possible to determine the nature of their interaction and "natural" properties: each of the subsystems is not a priori self-sufficient, doesn't have all the features and properties necessary to maintain its own homeostasis and therefore can't be stable in the long run... However, by interacting ... all four systems together support each other's homeostasis and the stability of the system as a whole" [3, p. 188 ]. Such interaction, in fact, causes synergy. 
Effective implementation of the resource concept is impossible without a thoroughly planned process approach. The process approach to the management of logistics flows dictates the need to apply the methodology of business process reengineering, taking into account the specifics of logistics. The combination of work procedures and operations into one is characterized by the absence of "assembly line" technology, in which simple tasks or work procedures are performed at each workplace. In the process approach to logistics flow management, procedures previously performed by different employees are integrated, resulting in horizontal process compression. According to experts, this compression accelerates the execution of processes by about 10 times [6]. In contrast to horizontal compression as a consequence of the process approach, independent decisionmaking by the executor provides vertical compression of processes and eliminates the need to spend time to apply to the top management structure.

According to Professor Kulik V.A. resourcefulness is one of the main properties of the logistics flow, along with such as: territorial location, target orientation, elemental structuring, process coherence, system organization, legal allocation, multiflow [6]. Disclosure of the essence and variety of properties of the logistics flow allowed identifying the substantial heterogeneity of the composition and multi-vector motion of individual elements of the logistics flow as an object of management in compliance with the established subordination of processes caused by its multi-flow [6].

It's difficult to disagree with the fact that the revolutionary transformations in the basic issues of military affairs have led to significant changes in the conditions of logistical support of forces with military property and services. There was a multiple increase in the volume of tasks to provide forces. Due to the further development of armaments and military equipment, the emergence of high-precision weapons, weapons on new physical principles, as well as changes in the methods of preparation and conduct of operations, the conditions for providing forces with military property and services have become sharply more complicated and increased. [11]. Therefore, the logistical support system for the preparedness for military operations in accordance with the purpose, has to be able to coordinate resources, equipment, information and people quickly, accurately, coordinated in conditions of constant instability and changes in time parameters. In order to achieve this feature of the logistics system, military logisticians propose to integrate NATO Logistics projects by creating a new structure for procurement, joining support and supply services. The result of such integration, in their opinion, will be achieved $[9,10,11]$ :

- improving the quality of military property, the responsibility of suppliers for product quality and trust in them and creation of a state guarantee system of the defense products quality;

- improving the system of outsourcing services, following the example of NATO member countries, where food services are provided by a structural unit of the Ministry of Defense, which is obliged to provide these services both in peacetime and in other cases;

- clarification of the division functions of providing military property to the Armed Forces between the Ministry of Defense and the General Staff;

- achieving compliance of the composition and capabilities of logistics management bodies, military units and institutions to the assigned tasks, taking into account the established number;

- improvement of methods of work and use of automated technical means, high technologies for the purpose of structure improvement and number of military management bodies, forces and providing means reduction;

- introduction of principles of conformity and mutual compatibility, structural management subdivisions and 
forces of maintenance in peacetime and wartime.

Based on the experience of NATO Logistics, military logisticians propose to optimize the support system of the Armed Forces of Ukraine. To this goal, it's proposed to achieve the maximum degree of autonomy at all operation levels of this system and implement the following measures $[9,10,11]$ :

- determination of the volume and order of separation of military property stocks taking into account the reduction of the combat and numerical composition of the Ukrainian Armed Forces, as well as their transition to a three-tier structure;

- reduction of redundant infrastructure, which doesn't directly affect the level of combat readiness of forces;

- improving organizational and economic forms of management, including by expanding the participation of the national economy civil sector in providing forces and modernization of technical equipment of logistics support classes (see above the Table 1);

- optimization of the training system of servicemen and civilian personnel in specialties belonging to the types of logistics and classes of military means.

It's worth noting the following feature of the approaches vision to the tasks of the logistical support system for the preparedness for military operations by military logisticians: separation of the logistic support for the rear zone from the zone of active combat operations. As a result, with such a vision, management decisions and approaches (requirements, tasks, principles, parameters) for the organization of support are also different. In our opinion, this fact explains the frequent failures or low-level quality of logistical support of certain facilities (subdivisions of the Armed Forces) in the conditions of changing parameters of supply (time, structure of logistics flows, suppliers, stakeholders, etc.) After all, the experience of conducting military operations in part of our country has shown that any changes in the zone of active hostilities require an immediate response from the rear and therefore quick change. This explains the reasons for the sudden change in the parameters of supply in the process of delivery, disbandment, redeployment, and so on. As a result, response delays are very critical and sometimes fatal. Therefore, such a narrow approach to the planning of operations for the logistic support of military facilities needs to be some adjusted.

Here is one of the key properties of the logistics system - adaptability. Thus, the planning of logistics operations can be effective only if the flexibility and adaptability of the entire logistics system. It's necessary to apply the system-process principle, which "forms a system of logistics activities processes and is guided by them in the presence of branched connections: direct and inverse, formal and informal, internal and external, vertical and horizontal [6, p. 57]. Namely, the direction of the principle is oriented simultaneously in three directions: on the structure of the system (subsystems) in general; on the chains of flow processes; on a complex of logistic functions (Fig. 1).

This multi-vector direction of logistics system management contributes to a significant increase in its flexibility and adaptability. In other words, this step will allow a systematic approach to the effective organization of key processes of logistics, subject to a radical change in supply parameters. It's worth noting that the implementation of all logistics operations on one's own is often unprofitable. This is due to various reasons: narrow functional orientation of the Armed Forces units; their overload with the performance of basic functions; insufficient of technical or staffing support; lack (insufficiency) of the necessary logistics infrastructure; impossibility (limitation) of financing non-target operations; the long duration of obtaining permits for a sudden change in supply parameters - a late response to changes; low profitability (high prime cost) of logistics operations due to suboptimal planning for objective reasons, etc. 


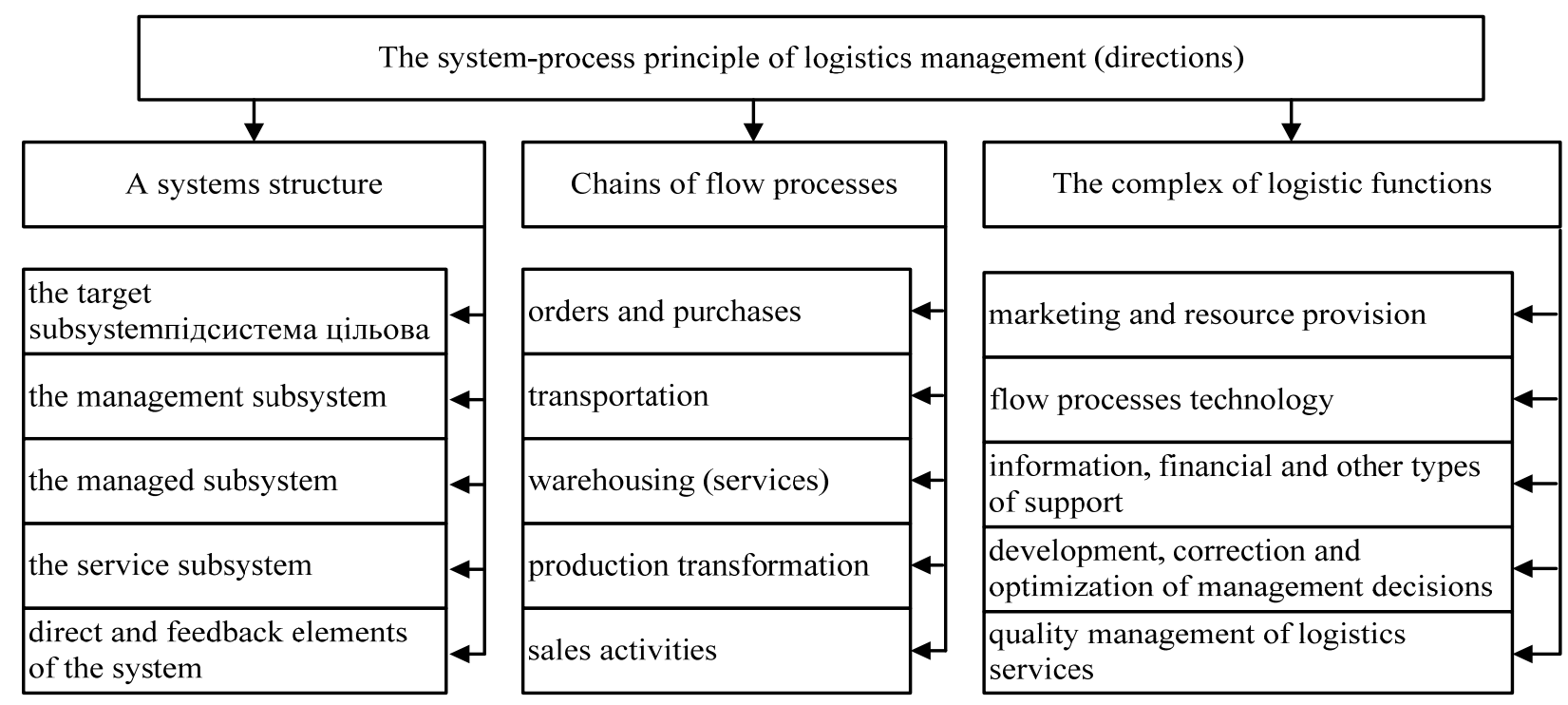

Fig. 1. The main provisions of the system-process principle of logistics management Source: [6, p. 57]

Of course, we are not talking about the supply of strategically important resources, manpower, information, etc. under the label "top secret". All operations that can be partially or fully to transfer to execution to the logistical provider should be outsourced. There is a fairly dense coverage of the routes of logistics transport companies, warehousing infrastructure, hubs, gas stations, service stations, medical infrastructure in the territory of Ukraine. In addition, there are a large number of potential partners for the army in the food industry, light industry, IT-manufacturers, consulting companies to improve the skills of personnel involved in logistics, etc. Of course, choosing a list of potential partners of the army is no less a responsible task. There are developed, protocol-approved algorithms at all levels of the Armed Forces. We propose to use the following algorithm to determine the feasibility of transferring "permitted" logistics operations to outsourcing (Fig. 2) [5]. 


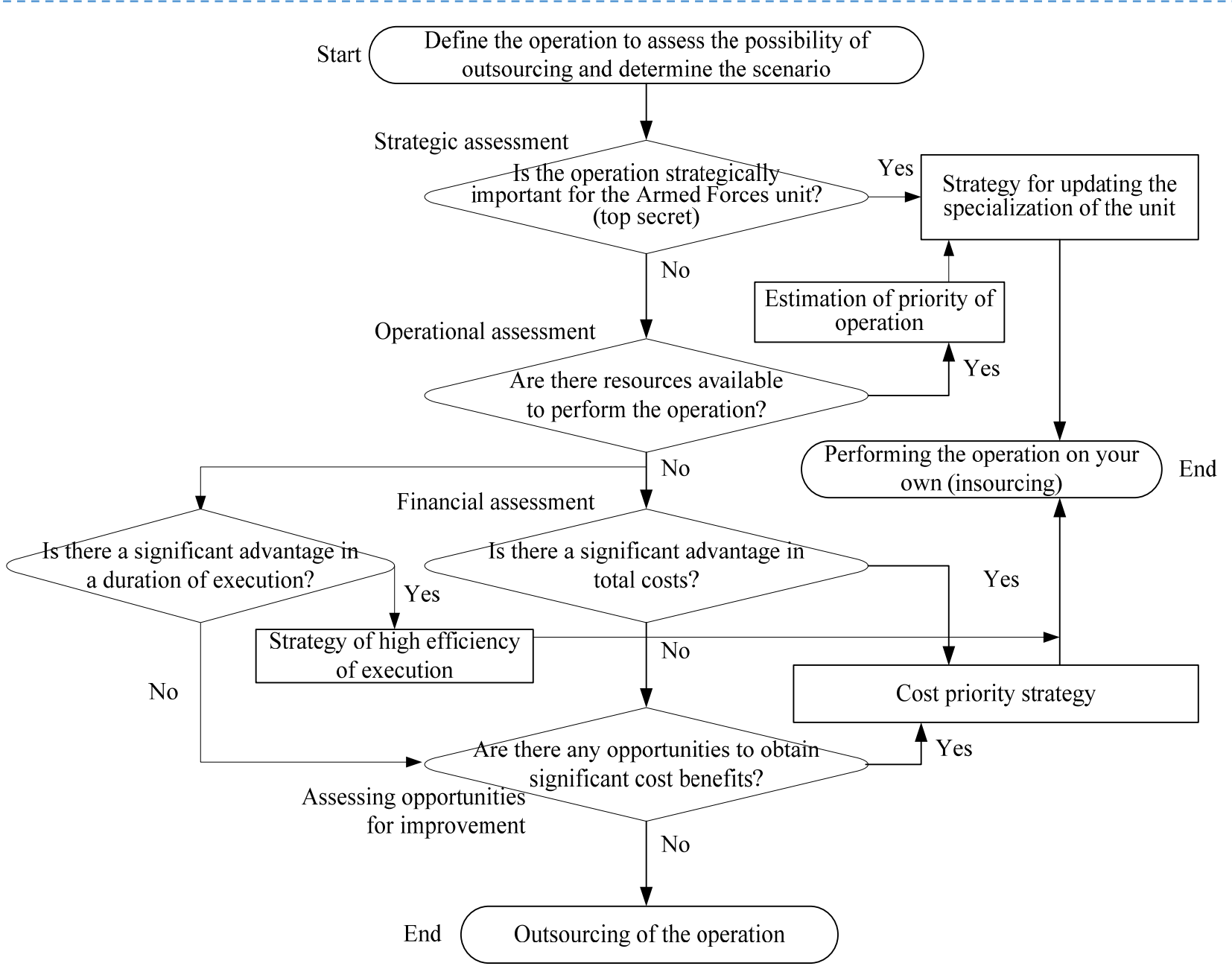

Fig. 2. Algorithm for determining the feasibility of outsourcing logistics operations. Source: developed by the author on the basis of [5]

The main factors that determine the feasibility of logistics outsourcing include: reducing the cost of work; reduction of time intervals for operations; service improvement; increase flexibility and achieve synergy effects; lack of knowledge and experience of the company in the field of logistics; strategic considerations, etc. The priority is to create a procedure that provides a clear sequence of selection and evaluation of matrix criteria (Fig. 3) [5]. 


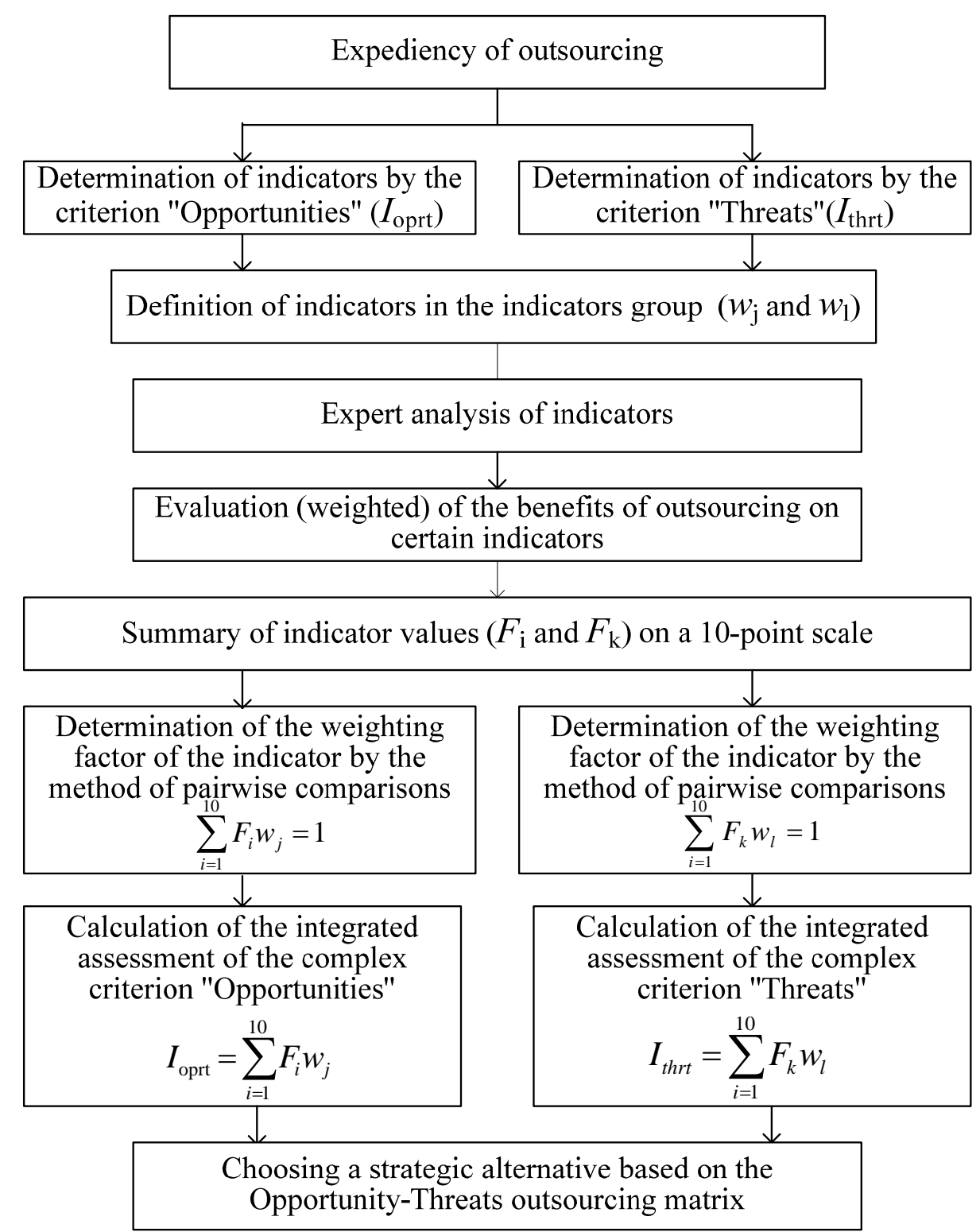

Fig. 3. The sequence of evaluation of the criteria for the transition to outsourcing for the outsourcing matrix "Threats - Opportunities"

Source: developed by the author on the basis of [7]

A generalized view of the "Outsourcing Matrix", which is filled with certain values of the calculated integrated indicators, is given on the Figure 4 [7]. 


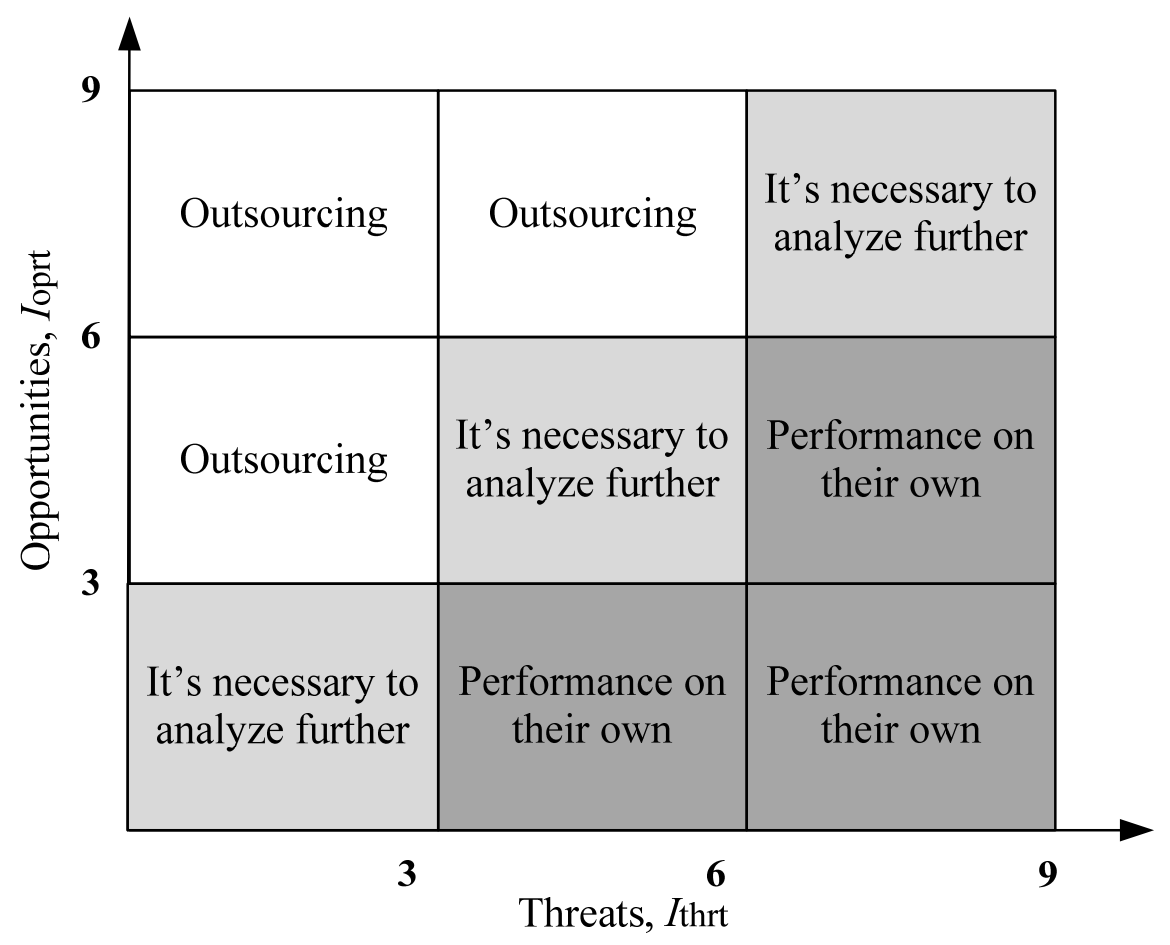

Source: developed by the author on the basis of [7]

Fig. 4. Outsourcing matrix

According to the above method, it is possible to make an informed decision on the feasibility of transferring a separate operation for logistics for the preparedness the Armed Forces for military operations and the selection of the optimal logistics provider or other strategic partner in the supply chain.

Conclusions. A science-analyzing of key elements supporting system of all participants in the logistics chain for the preparedness for military operations gives the following conclusions:

1) Traditional military delimitation of approaches to the implementation of the tasks of the logistical support system of the Armed Forces units for military operations, namely, the separation of the logistic support of the rear facilities from the zone of active combat operations, eliminates the possibility of achieving high efficiency, quality and profitability of tasks;

2) A high degree of bureaucracy in the army is superimposed on a low level of analytical assessment of the current situation in certain parts of the logistics chain, which as a result minimizes the practical implementation of the principles and methods of NATO Logistics (NATO standards);

3) A practical experience shows that performing all logistics operations on their own is often unprofitable. There is a need for an internal audit of own resources, technical and infrastructural base, partly information infrastructure, etc. in order to identify the causes of low efficiency of logistics operations;

4) Under modern conditions there is an urgent need to develop an acceptable adapted algorithm for finding a reasonable solution for the feasibility of transferring a separate operation to ensure the readiness of the Armed Forces units for military operations and select the optimal logistics provider or other strategic partner in the supply chain.

5) it's worth considering (to make additional research) the total resource potential of military logistics and in particular the logistic support system of units from the standpoint of their readiness to change, optimize and streamline the management of logistics flows in conditions of high risk; 
6) The military automation system developed by military specialists (it combines management automation tools into a single information space: decision support, bringing them to the executors, controlling, etc.) can also be used to address issues related to the outsourcing of individual logistics operations in real time. This tool will enable increase the efficiency of objective management decisions, as well as eliminate the influence of the human factor;

7) The implementation of these proposals will undoubtedly achieve a synergistic effect: powerful reduction of time expenses (is very critical in conditions of active combat operations), achieving high quality logistics operations, reducing the prime cost of operations (especially one-time operations or functionally unacceptable for military units), quick reaction to changing conditions, etc.

Of course, the start of such a project (including the described key elements) of the logistical support system of the Armed Forces units for military operations requires a powerful analysis, time and information base. However, each cycle of further application of the project will require only a certain adjustment of the procedures at the "entrance". But "at the exit" the army received: partial functional unloading of both units as a whole and individual personnel units; reduction of financial costs for logistics; faster response to changing conditions; higher degree of control over the implementation of coordination of logistics flows in space and time, etc.

These advantages will have a positive impact on the development of the military potential of the state as a whole. It should be clarified that the above proposals do not in any way contradict the creation of the Armed Forces of Ukraine of a new structure on procurement, joining the support and supply services, but only complement it. However, we have the opportunity to accelerate the practical implementation of NATO Logistics standards.

A more detailed study of the mechanism of functioning of the logistical support system of the Armed Forces units, as well as the conditions and tools of its functioning will be continued in future studies and presented in future publications.

\section{References}

1. Alkema, V.H. (2011) Systema ekonomichnoi bezpeky lohistychnykh utvoren: monografiy [The system of economic security of logistics entities]. Krok University of Economics and Law, Kyiv, Ukraine

2. Alkema, V.H. (2015) "The potential of the economic security system of the freight forwarding company". Project management and production development. [Online], vol.3, p.4360, available at: http://nbuv.gov.ua/UJRN/Uprv_2015_3_7.

3. Grigorak, M. Yu. (2017), Intelektualizatsiya rinku logistichnih poslug: kontseptsiya, metodologiya, kompetentnist: monografiy [Intellectualization of the logistics services market: concept, methodology, competence], Sik Grup Ukrayina, Kyiv, Ukraine.

4. Kostiuchenko L., Solomon D. (2020) "The basic terminology of the modern military logistics". Intellectualization of logistics and Supply Chain Management. [Online], vol.1, p.91-98, available at: https://smart-scm.org/en/journal-1-2020/lesia-kostiuchenko-solomon-dmitry-thebasic-terminology-of-the-modern-military-logistics/ (Accessed 30 May 2020). DOI: https://doi.org/10.46783/smart-scm/2020-1-8 
5. Kostiuchenko, L. (2020), "The methodology of enterprise logistic activity strategic analyse", Efektyvna ekonomika, [Online], vol. 5, available at: http://www.economy.nayka.com.ua/?op=1\&z=7872 (Accessed 20 Jul 2020).

6. Kulyk, V.A., Grigorak, M.lu. and Kostiuchenko (2013), Lohistychnyi menedzhment [Logistics management], Logos, Kyiv, Ukraine.

7. Mikalo, O.I. (2014), "The matrix method for estimating the reasonability of outsourcing in industrial enterprises". Efektyvna ekonomika, [Online], vol. 1, available at: http://www.economy.nayka.com.ua (Accessed Jun. 2014).

8. NATO Logistics Handbook (1997), Third Edition: October 1997, [Online], available at: https://www.nato.int/docu/logi-en/logist97.htm

9. Newsletter (2019) Bila knyha - 2018. Zbroini Syly Ukrainy [White Book - 2018. Armed Forces of Ukraine], Ministry of Defence Ukraine. [Online], available at: https://www.mil.gov.ua/content/files/whitebook/WB-2018.pdf

10. Resolution of the Cabinet of Ministers of Ukraine №1208 / 2018 “The order of logistical support of the defense forces during the implementation of tasks for the defense of the state, protection of its sovereignty, territorial integrity and inviolability" of Des 27, 2018, [Online], available at: https://zakon.rada.gov.ua/laws/show/1208-2018-\%D0\%BF\#Text

11. Scientific and practical webinar "Improving the logistics of the Armed Forces of Ukraine based on the experience of the joint forces operation". (Jun 24, 2020), National University of Defense of Ukraine named after I. Chernyakhovsky. [Online], available at: https://nuou.org.ua/u/news/naukovo-praktichnij-vebnar-\%E2\%80\%9Cudoskonalennya-logstikizbrojnix-sil-ukr.html.

12. Ukrainian Military Pages (2016) Stratehichnyi biuleten 2016: systema lohistyky i systema medychnoho zabezpechennia [Strategic Bulletin 2016: logistics system and health care system], [Online], available at: ukrmilitary.com/2016/12/logistic.html - Name from the screen.

13. Ukrainian Military Pages (2020) ZSU ochikuie velyke pereformatuvannia - plan na 10 rokiv [The AFU expects a major reformatting - a plan for 10 years] of Jan 11, 2020, [Online], available at: https://www.ukrmilitary.com/2020/01/new-army.html 